\title{
In silico studies of bioactive compounds from selected African plants with inhibitory activity against nitric oxide synthase and arginase implicated in asthma
}

Haruna Isiyaku Umar ${ }^{1,2^{*}}$ (D), Tolulope Peter Saliu', Sunday Solomon Josiah ${ }^{1}$, Adeola Ajayi ${ }^{1,2}$ and Jamilu Bala Danjuma ${ }^{3}$

\begin{abstract}
Background: It is a known fact that arginine is a common substrate for arginase and nitric oxide synthase (NOS). However, an imbalance between both enzymes could lead to a change in airway responses. Reports suggest that increased activities of both enzymes could lead to airway hyper-responsiveness. Thus, the requests for NOS inhibitors that can also inhibit arginase as the elevated activities of both enzymes have detrimental consequence on airways in asthma. Bioactive compounds from Azadirachta indica, Crinum glaucum, and Mangifera indica are documented for anti-inflammatory, immunomodulatory, anti-histaminic, smooth-muscle relaxants, and anti-allergic potentials. However, the mechanisms of action of these bioactive compounds in conferring the aforementioned protections are not well characterized. The objective of this present study is to assess in silico inhibitory potentials of these bioactive compounds against NOS and arginase via binding at their active sites. The crystal structures of NOS and arginase were retrieved from the protein database, while the bioactive compounds were retrieved from PubChem. Drug-likeness of the selected bioactive compounds was assessed using DruLiTo software. The successful compounds were docked with active sites of enzymes using AutoDock Vina docking software, and the docked complexes were analyzed using LigPlot and protein-ligand profiler web server.
\end{abstract}

Results: The findings of the study revealed that the bioactive compounds from A. indica, C. glaucum, and M. indica were able to interact with the active sites of NOS and arginase with the exception of gallic acid (from M. indica) and nimbandiol (from A. indica); these compounds showed differential binding energies $(\mathrm{kcal} / \mathrm{mol}$ ) and a number of them had higher binding energies than L-arginine when docked with NOS.

\footnotetext{
* Correspondence: ariwajoye3@gmail.com; uhumar@futa.edu.ng

${ }^{1}$ Department of Biochemistry, Federal University of Technology, P. M. B. 704,

Akure, Ondo State, Nigeria

${ }^{2}$ Computer-Aided Therapeutic Discovery and Design Group, FUTA, Akure,

Nigeria

Full list of author information is available at the end of the article
}

\section{Springer Open}

(c) The Author(s). 2021 Open Access This article is licensed under a Creative Commons Attribution 4.0 International License, which permits use, sharing, adaptation, distribution and reproduction in any medium or format, as long as you give appropriate credit to the original author(s) and the source, provide a link to the Creative Commons licence, and indicate if changes were made. The images or other third party material in this article are included in the article's Creative Commons licence, unless indicated otherwise in a credit line to the material. If material is not included in the article's Creative Commons licence and your intended use is not permitted by statutory regulation or exceeds the permitted use, you will need to obtain permission directly from the copyright holder. To view a copy of this licence, visit http://creativecommons.org/licenses/by/4.0/. 
Conclusion: Conclusively, the in silico analysis proposes that these compounds could prove to be probable antiasthmatic drugs.

Keywords: ADMET, Arginase, Asthma, Azadirachta indica, Crinum glaucum, In silico, Mangifera indica, Nitric oxide synthase

\section{Background}

Nitric oxide synthase (NOS) is an enzyme that catalyzes the conversion of L-arginine to L-citrulline and produces nitric oxide (NO) a tiny, short-lived molecule. Nitric oxide is no doubt a widely studied signaling molecules in biology [1]. The neuronal NOS (nNOS), endothelial NOS (eNOS), and inducible NOS (iNOS) till date are the three distinct isoforms of NOS [2]. While eNOS and nNOS are constitutively expressed depending on the increases in external calcium and also the binding of a calcium/calmodulin complex for activation. Both nNOS and eNOS play a pertinent role in neurotransmission and smooth muscle relaxation, while iNOS is usually expressed during bacterial infection, inflammation, and tumor cell lysis [2,3]. Arginase is an important and final enzyme of urea cycle that aid in the conversion of L-arginine to ornithine and urea. NOS and arginase share same substrate (L-arginine), thus both compete for the substrate. Elevated activity of arginase has been linked with numerous diseases by decreasing the supply of L-arginine required by NOS to produce NO, there by raising the production of L-ornithine which results in vascular structural problems. Actually, L-ornithine is converted into either polyamine such as putrescine, spermidine, and spermine or proline; in addition, these downstream products can promote cell proliferation and collagen production. Arginase is not limited to hepatocytes but also other cells in the lung and airways $[4,5]$.

Chronic asthma is categorized by airways constriction, inflammation, and airway hyper-responsiveness [6]. Though many processes of pathologic relevance partake in the pathogenesis of asthma, a huge body of evidence indicates the pivotal role of airway-derived nitric oxide (NO) in the mechanism that underlies asthma [7-10].
Interestingly, NO confers a bronchodilatory effect via the relaxation of airway's smooth muscle [9]. NO binds to soluble guanylate cyclase (sGC); this leads to activation of the protein, followed by enhanced production of intracellular messenger cGMP, which is responsible for initiating downstream signaling for vasodilation [10]. The injurious effects of $\mathrm{NO}$ in airway inflammation by reactive nitrogen species (RNS) formation is supported by substantial evidences [11]. Increased generation of RNS and reactive oxygen species (ROS) are well documented in asthma $[5,7,11,12]$. Therefore, an NOS inhibitor should also have an inhibiting effect on arginase, as the elevated amounts of either enzyme have detrimental effects on the lung airways in asthma (Fig. 1); consequently, two routes must undergo regulation in order to maintain the lung's internal environment [12]. Current asthma therapy lacks desirable outcomes owing to adverse consequences. Thus, patients are seeking medicines that are complementary and alternative to treat their asthma $[13,14]$.

Plants are ubiquitous in every livable environment, lot of which are found on land. Many stresses and challenges are faced by plants with being sedentary; they possess many molecules that prevent harms from animals and environmental affronts. Also, these molecules confer on plants the capability to give off scents, colors, and noxiousness. Several historical findings on the early use of plants for medicinal objectives following the discovery of many medicinal plants by our ancestors must have been through trial and error expedition necessitated by their quest to survive. Before the advent of recording and writing of history, such knowledge was passed through generations orally. Many plants were recorded in the early years of having medicinal

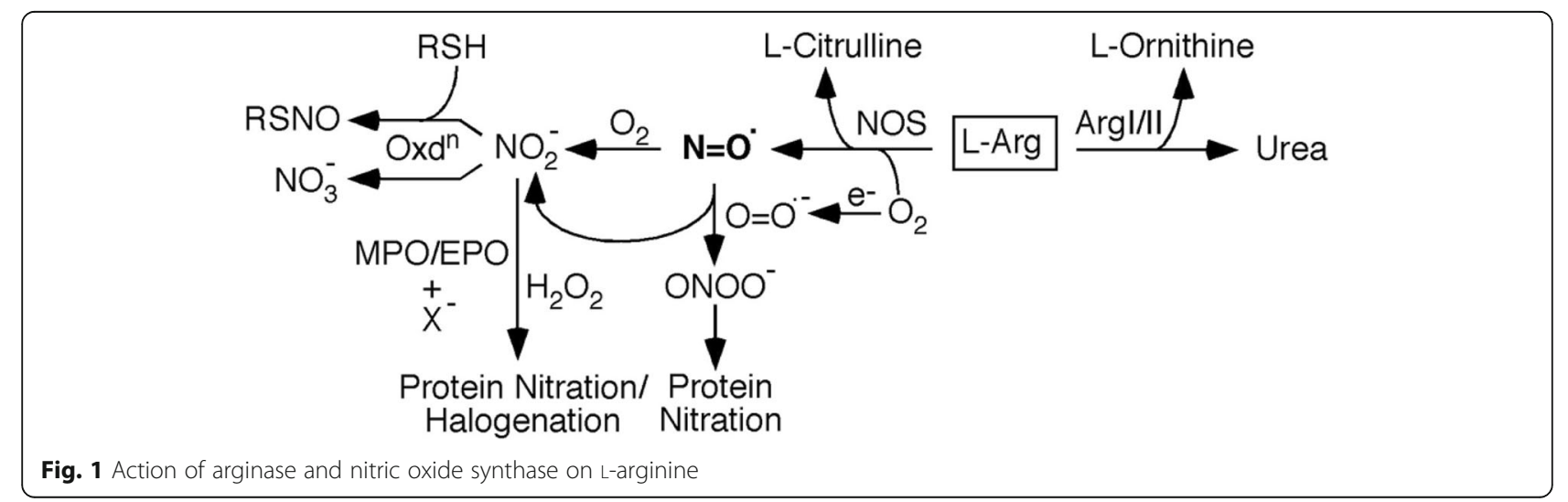


properties and were used to treat many pathological conditions [15-20]. Products from plants and animals are natural which have been a regular source of drugs for anticancer and antimicrobial agents. TradoMedicine has been dominated by contemporary medicine as the methods of treatment for human diseases. However, in year past, we have watched an increase in the use of medicinal plants for health promotion and treatment of diseases in many countries including developed countries such as the UK, Germany, China, and France where many medicinal plant extracts are now used as prescription drugs [21].

Attacks due to asthma can be treated or prevented by a variety of bronchodilator drugs such as albuterol, terbutaline, theophylline, and cromolyn sodium [22]. Conversely, there is a rising cost of imported medication to the extent that government cannot continue to meet the demands of the people. Besides, the scarcity and cost of the commodities used to manufacture drugs locally have made modern medicine most expensive for the common man to afford [23]. It is, therefore, important that we continually evaluate and develop our indigenous plant resources to enrich our traditional herbal therapy as well as source for additional raw materials for the local manufacturing of modern drugs. This is to ensure the improvement and sustenance of our health care system [24]. Medicinal plants employed in the treatment of this malaise should possess anti-inflammatory, antihistaminic, immunomodulatory, smooth-muscle relaxants, and anti-allergic activity [25]. Over the years, researchers have strengthened the determinations to isolate and characterize bioactive ingredients from such plants. Among the identified plants with anti-inflammatory, immunomodulatory, antihistaminic, smooth-muscle relaxants, and anti-allergic potential are Crinum glaucum, Mangifera indica, and Azadirachta indica. These valuable plants have been importantly noted for their uses in folkloric medicine for the management of various diseases including Asthma [26-45].

Crinum glaucum (Family: Amaryllidaceae), known commonly among the Yoruba speaking part of Nigeria as 'isumeri,' in Igbo of South East Nigeria as 'Ede Chukwu' or 'Ede mmo' (God's Cocoyam), and 'Albasar Kwa'adi' (Frog's Onions) in Hausa of Northern part of Nigeria, is a bulbs-bearing plant with thick, firm, upright, glaucous leaves. It has been reported as an efficient medicine to relief coughing, asthma, and convulsions, by trado-medical specialists [26-29]. The aqueous extract of C. glaucum bulbs had been revealed to generate a relaxant effect that is non-specific on smooth muscles of gastrointestinal tract, which also possess analgesic and antiinflammatory properties [28]. Similarly, the extract was also found to reduce the anaphylactic spasms of the guinea pig ileum along with the amount of spasmogens released anaphylactically from lung tissues [26]. Alkaloids are considered as the major bioactive components of C. glaucum which exhibits various pharmacological effects such as mast cell stabilization, anti-allergic effect, anti-spasmodic effect, and antianaphylactic effect [29]. From literature, Crinamine and Lycorine are the two alkaloids that may have anti-asthmatic effect [26, 29].

Mangifera indica (family: Anacardiaceae) is considered as one of the main tropical fruits in the world which originated from Asia. Besides, reports have shown that China, India, Brazil, Nigeria, Pakistan, Mexico, Thailand, and the Philippine are well-known for mango cultivation with India being the highest mango cultivating country $[30,31]$. Despite the common use of mango fruit as food, various parts of mango trees have also been used for medical purposes. One of such disease is asthma since ancient times, mostly in Southeast Asian and African countries [32]. Barretto et al. [33] characterized and quantified a wide range of polyphenolics in $M$. indica. Mangiferin, gallic acid, catechins, quercetin, kaempferol, protocatechuic acid, ellagic acids, propyl and methyl gallate, rhamnetin, and anthocyanins are the major polyphenolic compounds found in $M$. indica [34]. Several reports that laid claims to $M$. indica possessing anti-allergic, analgesic, antioxidant, anti-inflammatory, and immunomodulatory properties have been documented [29, 35-37].

Azadirachta indica (Neem), belonging to the family Meliaceae is an evergreen tree, is being considered as the most important and useful medicinal and evergreen popular tree that is fast growing found commonly in India, Africa, and America [38]. The major bioactive constituents that have been previously isolated and characterized from the neem leaf include nimbin, nimbindiol, nimbinine, quercetin, rutin, and $\beta$-sitoserol $[29,39,40]$. The neem leaf based on earlier reports possess various pharmacological effects such as anti-inflammatory, antioxidant, antimicrobial, mast cell stabilizers, and antiviral potentials [29, 41-45].

It would be of interest to carry out computational studies on the binding of phytochemicals from available medicinal plants with NOS and arginase, to gain detailed knowledge about their inhibitory mechanism with an unequivocal level of accuracy. Since various extracts obtained from diverse parts of $C$. glaucum, M. indica, and $A$. indica have been reported for their potency in the treatment of asthma; thus, molecular docking was carried out to elucidate the molecular basis of interaction and hence, inhibitory potential of the phytochemicals isolated from these important medicinal plants against NOS and arginase. In addition, the in silico toxicity profiling of the best hit compounds were evaluated. 


\section{Methods}

\section{Protein targets selection and preparation}

This was carried out as described in Sekar et al. [46]. The three-dimensional (3D) crystallographic structures of human endothelial NOS complexed with arginine (PDB code: 3NOS) and human arginase I in complex with known inhibitor methionine 2(S)-amino-6-boronohexanoic acid (Me-ABH) with PDB code: 3SJT were retrieved from the Protein Database (PDB) (www.pdb.org/pdb). Using the software Chimera $\odot$, version 1.13., (http://www. cgl.ucsf.edu/chimera), the proteins were prepared for docking via the removal of the co-crystallized ligand and water molecules to produce a nascent receptor.

\section{Ligand preparations}

The selected molecules were obtained in Simple Data format (SDF) from PubChem web-platform (https:// www.ncbi.nlm.nih.gov/pccompound) in 3D conformation and were consequentially converted into mole files deploying MarvinSketch@ software (ver. 15.11.30). Furthermore, the molecules were optimized with Merck molecular force field (MMFF94) in Avogadro (ver. 1.10). Fourteen molecules were selected for the study (Table 1); two (2) molecules for C. glaucum, and six (6) molecules each for $M$. indica and $A$. indica.

\section{Drug likeness screening}

To ensure the drug likeness of the selected molecules, they were analyzed using DruLiTo software. DruLiTo is a tool that calculates molecular properties such as $\log \mathrm{P}$ values, molecular weight, Hydrogen bond donors, and acceptors. Lipinski's rule of five was applied to select the probable molecules $[47,48]$. Here, the simple data files of the ligands under study were uploaded onto the software and were run to provide the druglikeness parameters to be predicted.

\section{Molecular docking}

The docking was done by using flexible docking protocol according to Sekar et al. [46], Trott and Olson [49], and Warshaneyan et al. [50]. Briefly; Python Prescription 0.8, a suite comprising of automated molecular docking tools (Auto Dock Vina), was utilized for the molecular docking analysis of the selected Ligands with the two enzymes. The PDBQT files of both proteins were generated through this software (using their previously created PDB files as inputs). The specific target sites of the two target enzymes separately were set with the help of grid box. Ten configurations for each Protein-Ligand complex were generated for all the ligands using the software; text files of scoring results were also produced for the purpose of manual comparative analysis at the end of the experiment.

\section{Molecular interaction analysis}

The protein-ligand complexes along with the molecular interaction were all visualized using PyMOL@ Molecular Graphics (version 2.4, 2010, Shrodinger LLC), $\operatorname{LigPlot}^{+}$(c) Roman Lakoskwi (version 2.1.), and the Protein-Ligand interaction profiler's web server (https://projects.biotec.tudresden.de/plip-web/plip) [51] and snapshots were taken.

\section{Prediction of ADMET properties}

The ADMET properties of the compounds with the highest hits from the molecular docking run were performed in ADMETSar web server (http://lmmd.ecust. edu.cn/). This is a web server where the hit compounds were accessed for their pharmacodynamics and pharmacokinetic properties using various model on the server.

\section{Results}

Selected protein targets

NOS have homodimeric chains (A and B) with resolution $2.40 \AA$. Further, 427 amino acids constitute the length of the protein co-crystalized with arginine substrate. Arginase I is homodimerically crystalized with $\mathrm{Me}-\mathrm{ABH}$, which is having a protein length of 322 amino acids and resolution of $1.60 \AA$ (Fig. 2).

\section{Drug likeness screening}

Bioactive compounds selected from the three different plants known for their anti-asthmatic properties for docking studies are presented in Table 1, which shows their chemical structures. Two out of Thirteen bioactive compounds that were assessed for druglikeness potentials possessed one or more violations and were eliminated from the study (Table 2). The remaining 11 molecules which satisfied Lipinski's rule of five were used for the docking studies.

\section{Molecular docking and interaction of NOS and phytocompounds}

The amino acid residues present at the site for catalytic action in NOS include Val104, Phe105, Pro106, Arg107, Ala181, Pro182, Arg183, Gln247, Arg250, Tyr331, Val336, Phe353, Ser354, Trp356, Tyr357, Glu361, Asn366, Asp444, Phe468, Ala472, and Arg474 $[3,52,53]$ while those present in the site of recognized by substrate in arginase-I are Pro20, Arg21, Lys68, His101, Asp124, Ala125, His126, Asp128, Asn130, Thr135, Thr136, Ser137, Asn139, His141, Gly142, Asp183, Asp232, Asp234, Thr246, and Glu277 [3, 5]. Tables 3 and 4 summarizes the docking study results, presented as binding energy and the molecular interactions that occur between these compounds and our protein targets.

In this in silico study, the entire bioactive compounds displayed inhibitory activity against NOS and arginase. 
Table 1 Chemical Structure of bioactive compounds in A. indica, C. glaucum, and M. indica

\begin{tabular}{|c|c|c|c|c|c|c|}
\hline $\mathrm{S} / \mathrm{N}$ & Plant Source & Ligands & Molecular weight & Chemical formula & Chemical structures & References \\
\hline \multirow[t]{5}{*}{1.} & Azadirachta indica & Nimbin & 540.24 & $\mathrm{C}_{30} \mathrm{H}_{36} \mathrm{O}_{9}$ & & {$[29,39,40]$} \\
\hline & & Nimbandiol & 456.21 & $\mathrm{C}_{26} \mathrm{H}_{32} \mathrm{O}_{7}$ & & \\
\hline & & Nimbinene & 482.23 & & & \\
\hline & & Quercetin & 302.04 & $\mathrm{C}_{15} \mathrm{H}_{10} \mathrm{O}_{7}$ & & \\
\hline & & Rutin & 610.15 & $\mathrm{C}_{27} \mathrm{H}_{30} \mathrm{O}_{16}$ & & \\
\hline \multirow[t]{2}{*}{2.} & Crinum glaucum & Crinamine & 301.342 & $\mathrm{C}_{17} \mathrm{H}_{19} \mathrm{NO}_{4}$ & & {$[26,29]$} \\
\hline & & Lycorine & 287.315 & $\mathrm{C}_{16} \mathrm{H}_{17} \mathrm{NO}_{4}$ & & \\
\hline 3. & Mangifera indica & Catechin & 290.08 & $\mathrm{C}_{15} \mathrm{H}_{14} \mathrm{O}_{6}$ & & {$[33,34]$} \\
\hline
\end{tabular}


Table 1 Chemical Structure of bioactive compounds in A. indica, C. glaucum, and M. indica (Continued)

\begin{tabular}{|c|c|c|c|c|c|c|}
\hline $\mathrm{S} / \mathrm{N}$ & Plant Source & Ligands & Molecular weight & Chemical formula & Chemical structures & References \\
\hline & & Ellagic acid & 302.01 & $\mathrm{C}_{14} \mathrm{H}_{6} \mathrm{O}_{8}$ & & \\
\hline & & Epicatechin & 290.08 & $\mathrm{C}_{15} \mathrm{H}_{14} \mathrm{O}_{6}$ & & \\
\hline & & Gallic acid & 170.02 & $\mathrm{C}_{7} \mathrm{H}_{6} \mathrm{O}_{5}$ & & \\
\hline & & Kaempferol & 286.05 & $\mathrm{C}_{15} \mathrm{H}_{10} \mathrm{O}_{6}$ & & \\
\hline & & Mangiferin & 422.08 & $\mathrm{C}_{19} \mathrm{H}_{18} \mathrm{O}_{11}$ & & \\
\hline 4. & Synthetic drug & Cromolyn Sodium & 512.03 & $\mathrm{C}_{23} \mathrm{H}_{14} \mathrm{Na}_{2} \mathrm{O}_{11}$ & & \\
\hline
\end{tabular}

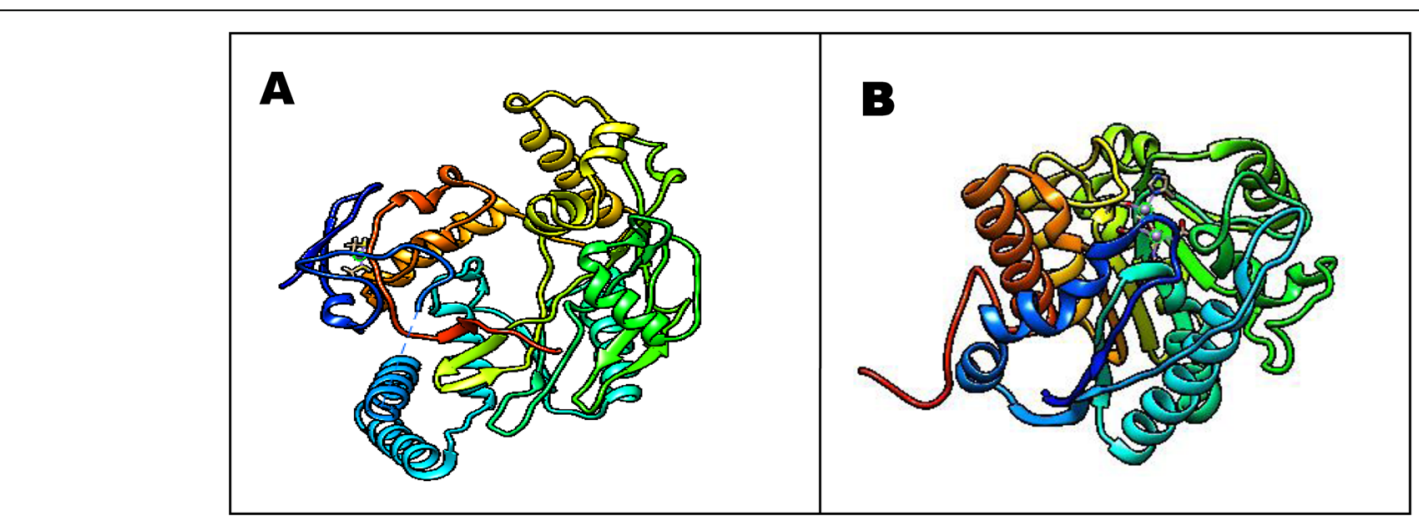

Fig. 2 Three-dimensional structures (in ribbon) of target proteins. a Nitric oxide synthase. b Arginase 
Table 2 Physicochemical properties of compounds calculated based on the Lipinski's rule of 5

\begin{tabular}{|c|c|c|c|c|c|c|c|}
\hline $\mathrm{S} / \mathrm{N}$ & Plant source & Ligands & Molecular weight & $\log P$ & No of HB donor & No of HB acceptor & No of violations \\
\hline \multirow[t]{5}{*}{1.} & Azadirachta indica & Nimbin & 540.24 & 1.276 & 0 & 9 & 1 \\
\hline & & Nimbandiol & 456.21 & -0.311 & 2 & 7 & 0 \\
\hline & & Nimbinene & 482.23 & 0.928 & 0 & 7 & 0 \\
\hline & & Quercetin & 302.04 & 1.834 & 5 & 7 & 0 \\
\hline & & Rutin & 610.15 & -0.735 & 10 & 16 & 3 \\
\hline \multirow[t]{2}{*}{2.} & Crinum glaucum & Crinamine & 301.342 & 0.613 & 1 & 5 & 0 \\
\hline & & Lycorine & 287.315 & -0.285 & 2 & 5 & 0 \\
\hline \multirow[t]{6}{*}{3.} & Mangifera indica & Catechin & 290.08 & 0.852 & 5 & 6 & 0 \\
\hline & & Ellagic acid & 302.01 & 1.366 & 4 & 8 & 0 \\
\hline & & Epicatechin & 290.08 & 0.852 & 5 & 6 & 0 \\
\hline & & Gallic acid & 170.02 & 0.964 & 4 & 5 & 0 \\
\hline & & Kaempferol & 286.05 & 1.486 & 4 & 6 & 0 \\
\hline & & Mangiferin & 422.08 & -0.631 & 8 & 11 & 2 \\
\hline 4. & Synthetic Drug & Cromolyn Sodium & 512.03 & 0.992 & 1 & 11 & 2 \\
\hline
\end{tabular}

The bioactive compounds of A. indica; nimbin, nimbindiol, nimbinene, and quercetin have binding energies of $-8.0,-8.2,-8.8$, and $-9.1 \mathrm{kcal} / \mathrm{mol}$ respectively with NOS. They also made interactions with several residues of amino acid found within the substrate recognizing site in NOS that were reported earlier $[3,52,53]$, and are indicated in bold letters (Tables 3 and 4). This shows that these bioactive compounds penetrate deeply into the site of substrate recognition in NOS (Fig. 3a-d). Nimbin established hydrogen bond with Gln247 and Glu361, and interacted hydrophobically with Phe353. Nimbandiol established hydrogen bond with Val185, Gly186, Gly355, and Trp356, and it formed a hydrophobic bond with Trp178, Val336, and Trp447; its aromatic ring

Table 3 Analysis of molecular interaction for the Phytochemicals with NOS

\begin{tabular}{|c|c|c|c|c|c|c|c|}
\hline $\mathrm{S} / \mathrm{N}$ & Plant source & Phytochemicals & $\begin{array}{l}\text { Number of } \\
\text { hydrogen } \\
\text { bond formed }\end{array}$ & $\begin{array}{l}\text { Residues involved } \\
\text { in hydrogen bond } \\
\text { formation }\end{array}$ & $\begin{array}{l}\text { Residues involved } \\
\text { in hydrophobic } \\
\text { interaction }\end{array}$ & $\begin{array}{l}\text { Residues } \\
\text { involved in } \\
\pi \text {-stacking }\end{array}$ & $\begin{array}{l}\text { Binding } \\
\text { energy } \\
\text { (kcal/mol) }\end{array}$ \\
\hline \multirow[t]{4}{*}{1.} & Azadirachta indica & Nimbin & 2 & Gln247, Glu361 & Phe353 & - & -8.0 \\
\hline & & Nimbandiol & 4 & $\begin{array}{l}\text { Val185, Gly186, Gly355, } \\
\text { Trp356 }\end{array}$ & Trp178, Val336 Trp447 & Trp447 & -8.2 \\
\hline & & Nimbinene & 2 & Gln247, Gly355 & $\begin{array}{l}\text { Gln247, Pro334, Val336, } \\
\text { Phe353 and Trp447 }\end{array}$ & - & -8.8 \\
\hline & & Quercetin & - & - & Leu193, Phe353 & Trp178 & -9.1 \\
\hline \multirow[t]{2}{*}{2.} & Crinum glaucum & Crinamine & 2 & Gly355, Trp356 & Phe353 & Trp178 & -9.2 \\
\hline & & Lycorine & 2 & Gly355, Trp356 & Val185, Val418, Ala423 & - & -8.5 \\
\hline \multirow[t]{5}{*}{3.} & Mangifera indica & Catechin & - & - & Leu193, Phe353 & Trp178 & -8.8 \\
\hline & & Ellagic acid & 4 & $\begin{array}{l}\text { Arg183, Ser354, Trp356 } \\
\text { and Glu361 }\end{array}$ & Trp178, Phe353 and Phe473 & Trp178 & -8.7 \\
\hline & & Epicatechin & 2 & Ser226 and Ala227 & Ala181, Phe353 and Phe473 & Trp178 & -8.4 \\
\hline & & Gallic acid & 3 & $\begin{array}{l}\text { Asp444, Asn466 and } \\
\text { Tyr475 }\end{array}$ & Pro106 and Phe468 & - & -5.9 \\
\hline & & Kaempferol & 1 & Trp356 & Trp178, Leu193 and Phe353 & Trp178 & -9.3 \\
\hline 4. & Synthetic Drug & Cromolyn Sodium & 7 & $\begin{array}{l}\text { Arg107, Asn180, Arg183, } \\
\text { Gly355, Trp356, Leu469, } \\
\text { Phe473 }\end{array}$ & $\begin{array}{l}\text { Trp178, Phe353, Phe468, } \\
\text { Ala472, Phe473, Tyr475 }\end{array}$ & Trp178 & -10.7 \\
\hline 5. & Substrate & $\mathrm{N}$-Omega-L-arginine & 7 & $\begin{array}{l}\text { Gln247, Tyr331, Gly355, } \\
\text { Trp356, Tyr357, Glu361 } \\
\text { and Asn366 }\end{array}$ & Val336 and Tyr357 & - & -5.9 \\
\hline
\end{tabular}


Table 4 Analysis of molecular interaction for the phytochemicals with Arginase-l

\begin{tabular}{|c|c|c|c|c|c|c|c|}
\hline $\mathrm{S} / \mathrm{N}$ & Plant source & Phytochemicals & $\begin{array}{l}\text { Number of } \\
\text { hydrogen } \\
\text { bond formed }\end{array}$ & $\begin{array}{l}\text { Residues involved } \\
\text { in hydrogen bond } \\
\text { formation }\end{array}$ & $\begin{array}{l}\text { Residues involved } \\
\text { in hydrophobic } \\
\text { interaction }\end{array}$ & $\begin{array}{l}\text { Residues } \\
\text { involved in } \\
\pi \text {-stacking } \\
\end{array}$ & $\begin{array}{l}\text { Binding } \\
\text { energy } \\
(\mathrm{kcal} / \mathrm{mol}) \\
\end{array}$ \\
\hline \multirow[t]{4}{*}{1.} & \multirow[t]{4}{*}{$\begin{array}{l}\text { Azadirachta } \\
\text { indica }\end{array}$} & Nimbin & 4 & $\begin{array}{l}\text { Asn130, Thr136, Ser137 } \\
\text { And Asn139 }\end{array}$ & His126 And Thr246 & - & -6.1 \\
\hline & & Nimbandiol & 4 & $\begin{array}{l}\text { Ser137, Asn139, His141 } \\
\text { And Gly142 }\end{array}$ & His126 And Thr246 & - & -5.9 \\
\hline & & Nimbinene & 1 & Gly185 & Thr134, Leu152 And Tyr188 & Tyr188 & -6.3 \\
\hline & & Quercetin & 3 & His141, Asp181 And Glu277 & Thr246 & His126 and His141 & -7.4 \\
\hline \multirow[t]{2}{*}{2.} & \multirow{2}{*}{$\begin{array}{l}\text { Crinum } \\
\text { glaucum }\end{array}$} & Crinamine & 2 & Asn130 And Asp181 & His126 & His126 and His141 & -7.1 \\
\hline & & Lycorine & 1 & His126 & Thr246 & His141 & -7.0 \\
\hline \multirow[t]{5}{*}{3.} & \multirow[t]{5}{*}{$\begin{array}{l}\text { Mangifera } \\
\text { indica }\end{array}$} & Catechin & 5 & $\begin{array}{l}\text { Asp128, Ser137, His141, } \\
\text { Asp183 And Asp234 }\end{array}$ & Thr246 & His126 and His141 & -7.0 \\
\hline & & Ellagic acid & 6 & $\begin{array}{l}\text { Arg21, Asn130, Ser137, } \\
\text { Asn139, Gly142 and Glu186 }\end{array}$ & Thr246 & - & -8.3 \\
\hline & & Epicatechin & 5 & $\begin{array}{l}\text { Thr136, Ser137, Asn139, } \\
\text { His141 and Glu277 }\end{array}$ & Thr246 & His126 and His141 & -7.9 \\
\hline & & Gallic acid & 4 & $\begin{array}{l}\text { Asp128, Asn130, Ser137 } \\
\text { and Asp183 }\end{array}$ & His126 & His126 and His141 & -6.5 \\
\hline & & Kaempferol & 5 & $\begin{array}{l}\text { Arg21, Asp128, Ser137, } \\
\text { Asn139 and His141 }\end{array}$ & His126 and Thr246 & - & -6.8 \\
\hline 4. & $\begin{array}{l}\text { Synthetic } \\
\text { drug }\end{array}$ & $\begin{array}{l}\text { Cromolyn } \\
\text { Sodium }\end{array}$ & 3 & Ser137, Asn139 And Gly142 & - & - & -7.3 \\
\hline
\end{tabular}

Residues in bold letters are those found within the binding pocket of Arginase-I
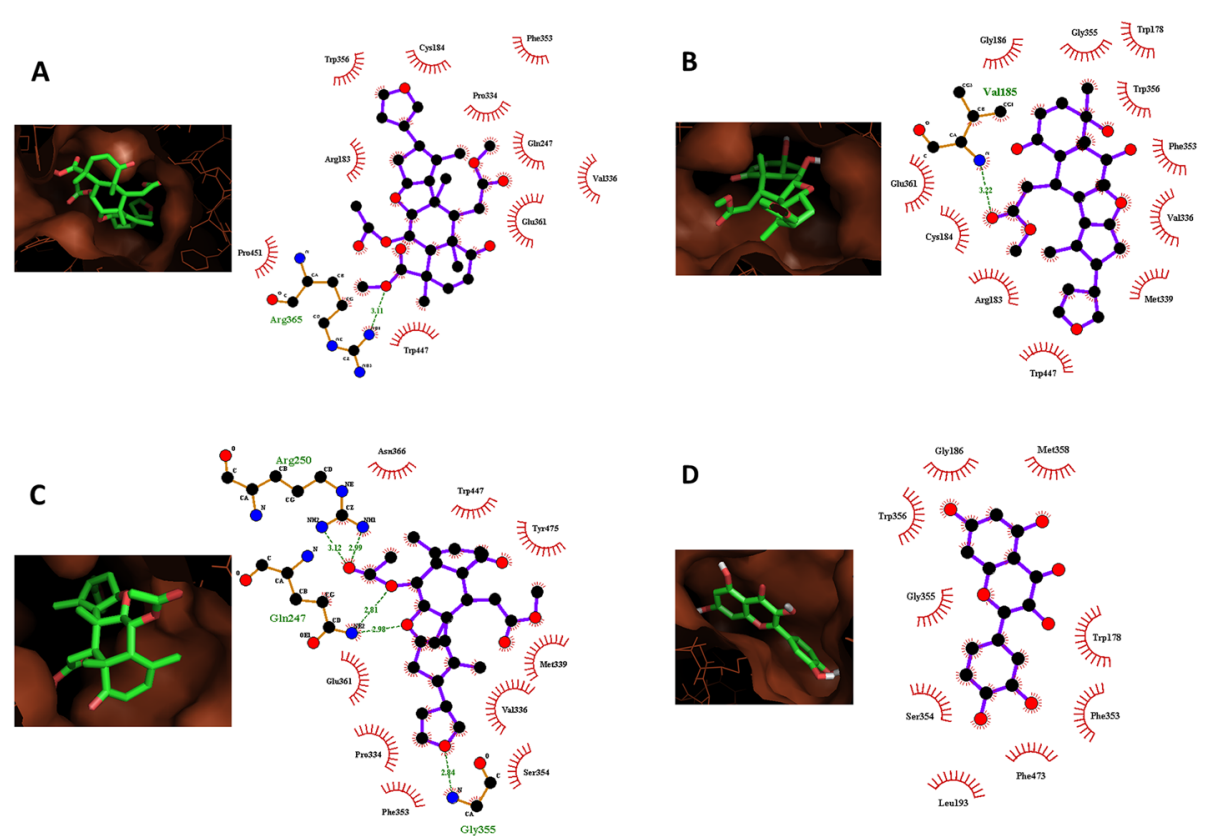

Fig. 3 The binding configuration of A. indica phytoconstituents and interaction analysis. Binding poses of a Nimbin, $\mathbf{b}$ Nimbandiol, c Nimbinene, and $\mathbf{d}$ Quercetin on NOS active site as obtained from molecular docking using AutoDock Vina. Result of 2D interaction analysis shows hydrogen bond (green dashed lines) and hydrophobic interaction (red curved lines) using LigPlot 

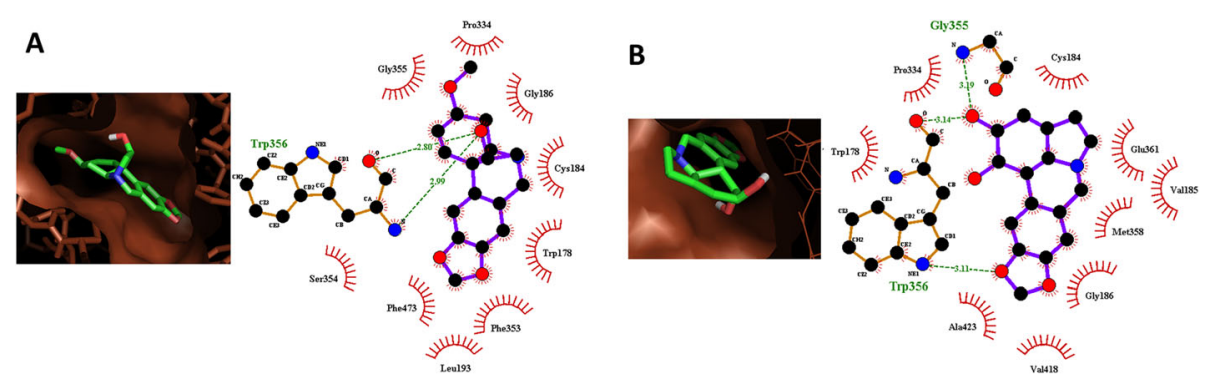

Fig. 4 The binding configuration of C. glaucum phytoconstituents and interaction analysis. Binding poses of a Crinamine and $\mathbf{b}$ Lycorine on NOS active site as obtained from molecular docking using AutoDock Vina. Result of 2D interaction analysis shows hydrogen bond (green dashed lines) and hydrophobic interaction (red curved lines) using LigPlot

interacted via $\pi$-stacking with Trp447. Nimbinene interacted with Gln247 and Gly355 by establishing hydrogen bonds while hydrophobic interaction was established with Gln247, Pro334, Val336, Phe353, and Trp447. Quercetin has no hydrogen bond interaction with any residues of the amino acid but establishes hydrophobic contact with Leu193 and Phe353, and its aromatic ring interacted via $\pi$-stacking with Trp178.

In C. glaucum, Crinamine and Lycorine have binding energies of -9.2 and $-8.5 \mathrm{kcal} / \mathrm{mol}$ respectively. Both bioactive

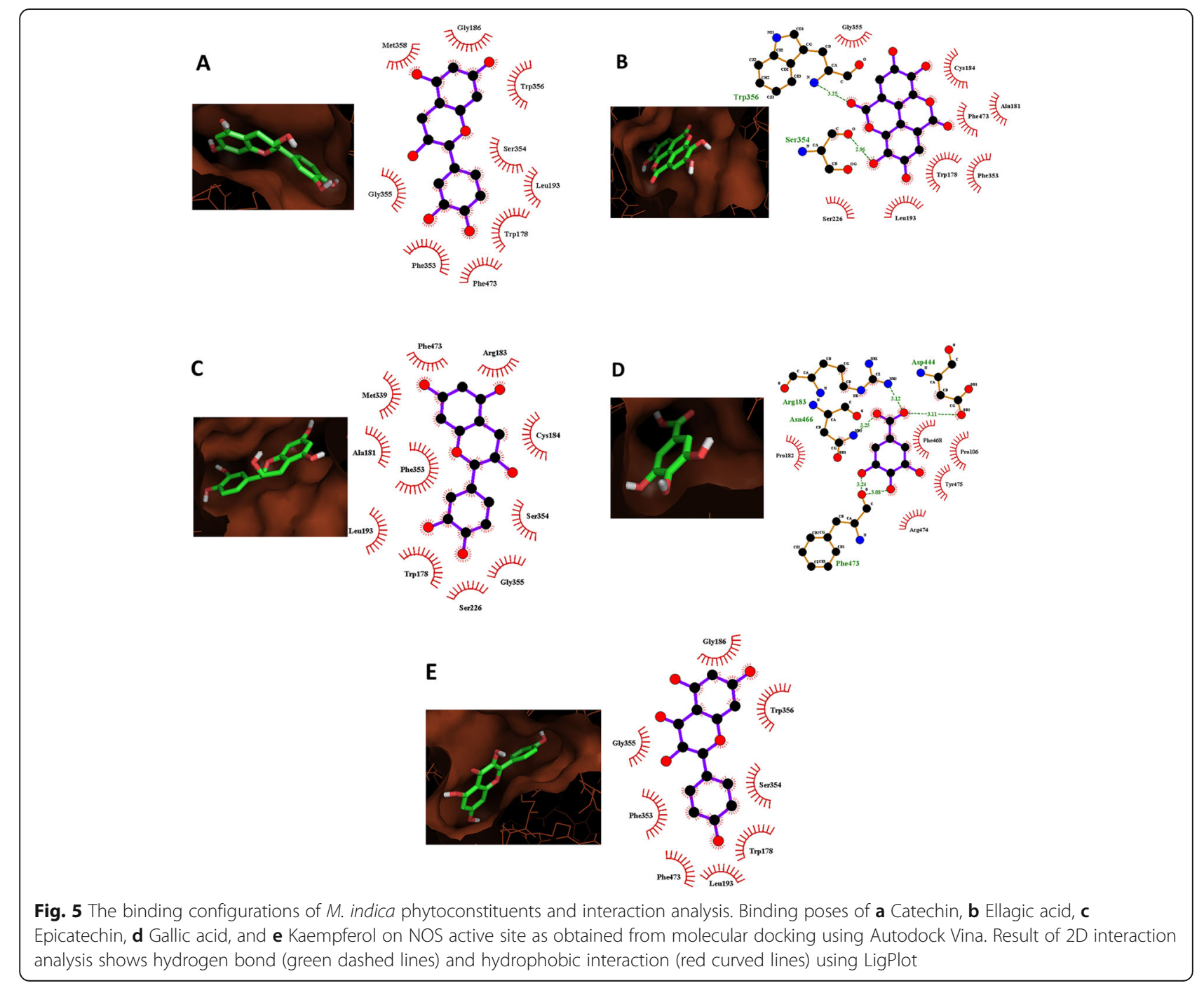


compounds penetrate deeply into the site for substrate metabolism in NOS and establish hydrogen bond interaction with Gly355 and Trp356 (Fig. 4a, b). This was due to the fact that both compounds shared common scaffold (Table 1). Crinamine interacted with Phe353 hydrophobically while its aromatic ring interacted via $\pi$-stacking with trp178. Lycorine interacted with Val185, Val418, and Ala423 hydrophobically.

The bioactive compounds in $M$. indica are catechin, ellagic acid, epicatechin, gallic acid, and kaempferol have binding energies of $-8.8,-8.7,-8.4,-5.9$, and -9.3 $\mathrm{kcal} / \mathrm{mol}$ respectively with NOS. Figure $5 \mathrm{a}-\mathrm{e}$ revealed that catechin interacts with Leu193 and Phe353 hydrophobically and does not form any hydrogen bond with residues within the active cavity in NOS, but its aromatic ring interacts via $\pi$-stacking with $\operatorname{Trp} 178$. Ellagic acid established hydrogen bond with Arg183, Ser354, Trp356, and Glu361 and interacted with Trp178, Phe353, and Phe473 hydrophobically. Furthermore, there was interaction between ellagic acid via its aromatic ring and Trp178 by $\pi$-stacking. Epicatechin formed hydrogen bond with Ser226 and Ala227; interacted hydrophobically with Ala181, Phe353, and Phe473 but interacted with Trp178 via $\pi$-stacking. The hydrogen bond formed by gallic acid were with residues; Asp444, Asn466, and Tyr475, while it established hydrophobic interactions with Pro106 and Phe468. Finally, Kaempferol established hydrogen bond with Trp356 and interacted with Trp178, Leu193, and Phe353 hydrophobically. There is an interaction between the aromatic ring of Kaempferol and Trp178 via $\pi$-stacking. The binding energy of the cocrystallized compound (L-arginine) was $-5.9 \mathrm{kcal} / \mathrm{mol}$ and it enjoyed hydrogen bond interaction with $G \ln 247$, Tyr331, Gly355, Trp356, Tyr357, Glu36, and Asn366, and hydrophobic interaction with Val336 and Tyr357.

\section{Molecular docking and interaction of Arginase-I and phytocompounds}

Docking results between the bioactive compounds of $A$. indica, C. glaucum, and $M$. indica with Arginase-I are presented in Figs. 6, 7, and 8 and Table 4. Bioactive compounds in $A$. indica; nimbin, nimbindiol, nimbinene, and quercetin have binding energies of $-6.1,-5.9,-6.3$, and $-7.4 \mathrm{kcal} / \mathrm{mol}$ respectively with arginase. They also made interactions with several residues of amino acid in the substrate's active slot of arginase which is in tandem with earlier reports [3, 5], as indicated in bold letters (Table 4). This present finding revealed that these bioactive compounds penetrate deeply into the active site of arginase. Nimbin established hydrogen bond with Asn130, Thr136, Ser137, and Asn139, and interacted hydrophobically with His126 and Thr246. Nimbandiol established hydrogen bond with Ser137, Asn139, His141, and Gly142, and it formed a hydrophobic bond withHis126 and Thr246. Nimbinene interacted with Gly185 by establishing hydrogen bond while hydrophobic interaction was established with Thr134, Leu152, and Tyr188, and its aromatic ring interacted via $\pi$-stacking with Trp188. Quercetin formed hydrogen bond interaction with His141, Asp181, and Glu277; it established hydrophobic contact with Thr246, and its aromatic ring interacted via $\pi$-stacking with His126 and His141.
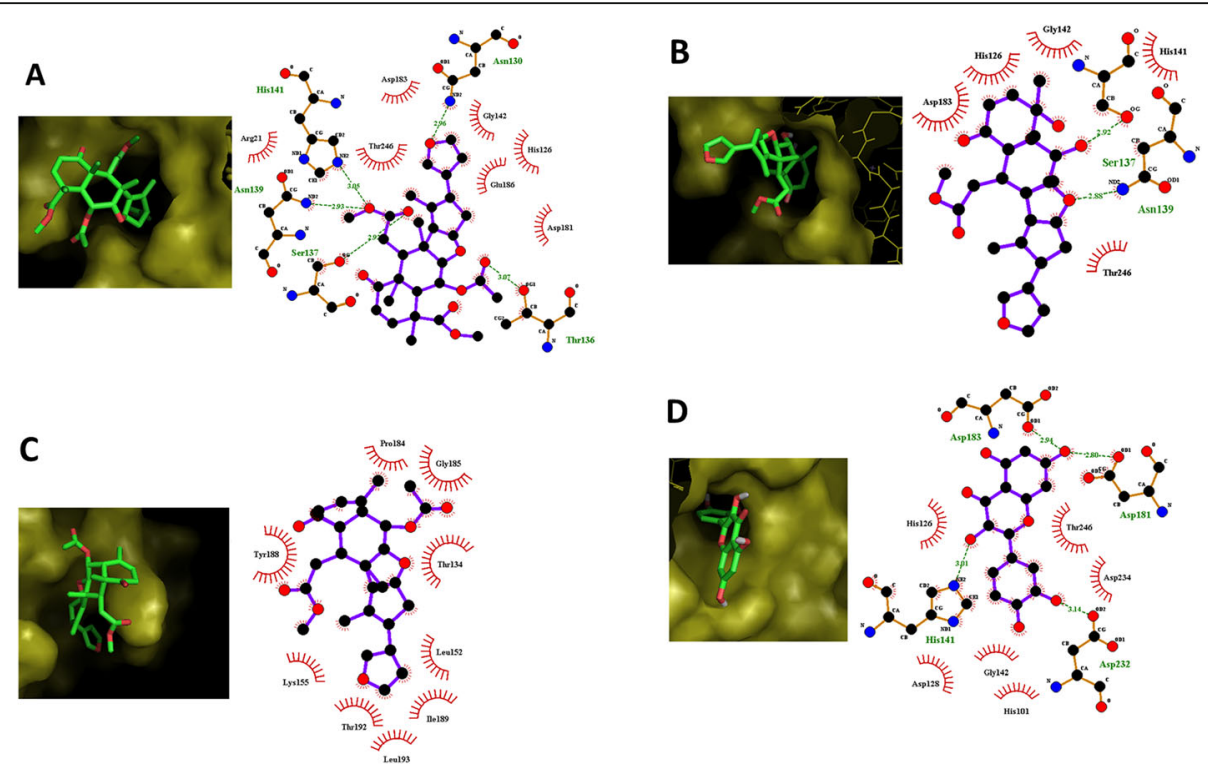

Fig. 6 The binding configuration of A. indica phytoconstituents and interaction analysis. Binding poses of a Nimbin, b Nimbandiol, c Nimbinene, and $\mathbf{d}$ Quercetin on Arginase-l active site as obtained from molecular docking using AutoDock Vina. Result of 2D interaction analysis shows hydrogen bond (green dashed lines) and hydrophobic interaction (red curved lines) using LigPlot 

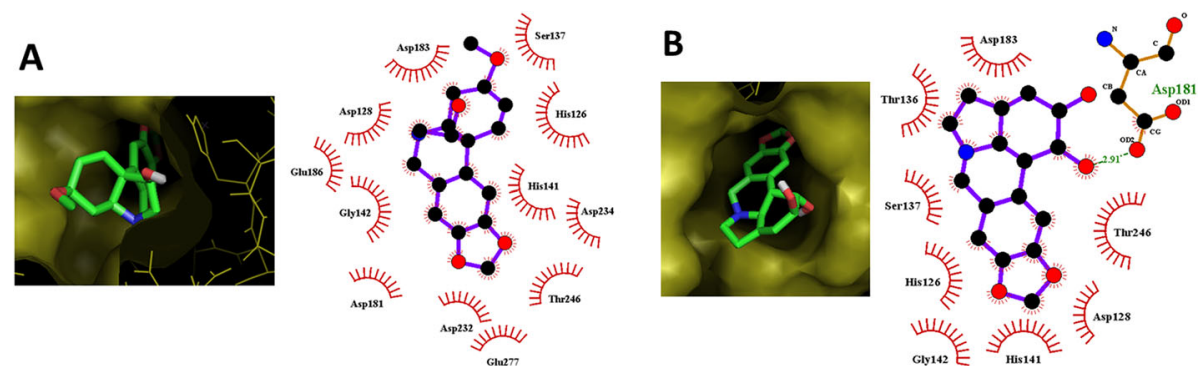

Fig. 7 The binding configuration of C. glaucum phytoconstituents and interaction analysis. Binding poses of $\mathbf{a}$ Crinamine and $\mathbf{b}$ Lycorine on arginase I active site as obtained from molecular docking using AutoDock Vina. Result of 2D interaction analysis shows hydrogen bond (green dashed lines) and hydrophobic interaction (red curved lines) using LigPlot
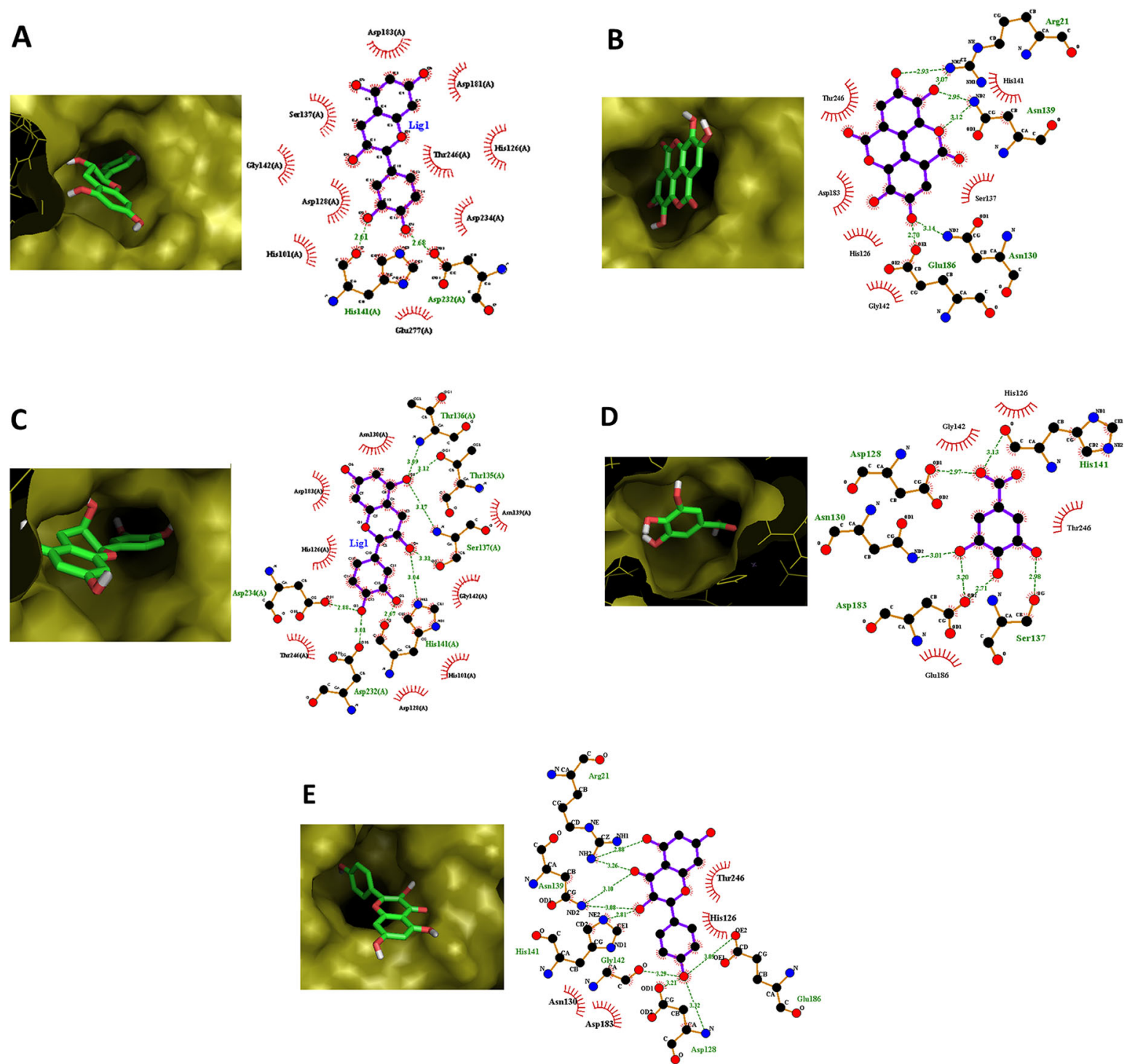

Fig. 8 The binding configuration of M. indica phytoconstituents and interaction analysis. Binding poses of a Catechin, b Ellagic acid, c Epicatechin, $\mathbf{d}$ Gallic acid, e Kaempferol on arginase I active site as obtained from molecular docking using Autodock Vina. Result of 2D interaction analysis shows hydrogen bond (green dashed lines) and hydrophobic interaction (red curved lines) using LigPlot 
The bioactive compounds of $C$. glaucum (Crinamine and Lycorine) have binding energies of -7.1 and -7.0 $\mathrm{kcal} / \mathrm{mol}$ respectively. Both bioactive compounds penetrate deeply into the active port of arginase. Crinamine establish hydrogen bond with Asn130 and Asp181; it interacted hydrophobically with His126, while its aromatic ring interacted via $\pi$-stacking with His126 and His141. Lycorine interacted with His126 by hydrogen bond, it hydrophobically interacted with Thr246, and its aromatic ring interacted via $\pi$-stacking with His141.

The bioactive compounds in $M$. indica viz catechin, ellagic acid, epicatechin, gallic acid, and kaempferol have binding energies of $-7.0,-8.3,-7.9,-6.5$, and -6.8 $\mathrm{kcal} / \mathrm{mol}$ respectively with arginase as seen in Fig. 8a-e and Table 4. Catechin established hydrogen bond with Asp128, Ser137, His141, Asp183, and Asp234 and interacts with Thr246 hydrophobically but its aromatic ring interacts via $\pi$-stacking with His126 and His141. Ellagic acid established hydrogen bond with Arg21, Asn130, Ser137, Asn139, Gly142, and Glu186. Also, it interacted with Thr246 hydrophobically while its aromatic ring interacted with His126 and His141 through $\pi$-stacking. Epicatechin formed hydrogen bond with Thr136, Ser137, Asn139, His141, and Glu277; and interacted hydrophobically with Thr246; and via $\pi$-stacking, epicatechin interacted with His126 and His141. The hydrogen bond formed by Gallic acid were with residues; Asp128, Asn130, Ser137, and Asp183, while it established hydrophobic interactions His126. Finally, Kaempferol established hydrogen bond with Arg21, Asp128, Ser137, Asn139, and His141; and interacted with His126 and Thr246 hydrophobically.

\section{ADMET profiling of hit compounds}

ADMET properties were predicted through the pharmacokinetic parameters in ADMETSar server (http://lmmd. ecust.edu.cn/) for ten hit compounds with cromolyn sodium (control) after a successful docking study (Table 5). All the hit compounds possess low absorption in the intestine via Caco-2 permeability except crinamine and lycorine which might be due to their molecular size, while they had high gastrointestinal absorption (GIA). The control drug and five hit compounds were predicted to penetrate the blood brain barrier (BBB). All hit compounds exhibited high plasma protein binding rate but the control drug had a low binding rate. This might affect their movement to target site where they exert their pharmacological actions. Most of them (9) were predicted to reside in mitochondria while only one was localized in the lysosomes. For drug metabolism, none of the compounds would be metabolize by CYP2D6 except four hit compounds, and three of them might likely inhibit CYP2D6. Kaempferol, lycorine, and quercetin might inhibit CYP1A2, while kaempferol was predicted to inhibit both
CYP2C19 and 2C9. Six hit compounds might serve as substrate to CYP3A4, while kaempferol, nimbin, nimbinin, and quercetin might likely inhibit CYP3A4 as predicted. All compounds predictively showed toxicity from Salmonella typhimurium reverse mutation assay (AMES) toxicity except four compounds. None were predicted to be carcinogenic. Five compounds were predicted to cause hepatotoxicity in humans except cromolyn sodium and other five hit compounds. Only three hit compounds could block human either-a-go-go (herG), a potassium ion channel which play a significant role in the repolarization of the heart.

\section{Discussion}

Molecular docking discovers the binding geometry of two interacting molecules with known structures. It predicts the preferred orientation of receptor (protein) and ligand (bioactive compounds) to each other to form a stable complex [54-57]. Currently, the use of computers to determine the binding of datasets of small molecules to known receptors is a major component of drug discovery. The top docking hits used in the present study does not violate Lipinski rule of five parameters. Lipinski rule of five is a law to evaluate drug likeness to define if a compound has a certain activity of pharmacological or biological relevance to make it a drug that is orally active in human $[47,48,54]$. The compound that go beyond molecular weight $\left(\mathrm{M}_{\mathrm{w}}\right)>500 \mathrm{Da}$, calculated $\log P>5$, hydrogen-bond donors $>5$, hydrogen-bond acceptors $>$ 10 is not likely to be pursued further as a drug with potentials, as this might likely loss properties significant that is linked with its absorption, distribution, metabolism, and excretion [47, 48, 54, 57, 58]. From this study, we found rutin and Mangiferin from $A$. indica and $M$. indica, respectively with the standard drug (cromolyn sodium) used in the study also exhibited questionable drug-like properties as shown in Table 2.

Increased activity of NOS leads to increased synthesis of the gaseous molecule, nitric oxide (NO). The oxidative environment of the asthmatic airway with high level of $\mathrm{NO}$ can lead to enormous formation of reactive nitrogen species (RNS) followed by subsequent oxidation and nitration of proteins, which adversely disturb protein functions with biological relevance to chronic inflammation [9, 10, 12]. Thus, NOS inhibition may offer therapeutic benefits in the treatment of asthma. However, increase in arginase activity beyond normal due to high level of arginine may involve in asthmatic pathogenesis following a decline in NO production and thereby promoting cell propagation and deposition of collagen in the airways $[3,4,9,10]$. In view of these, a good NOS inhibitor should also possess some degree of inhibition on 


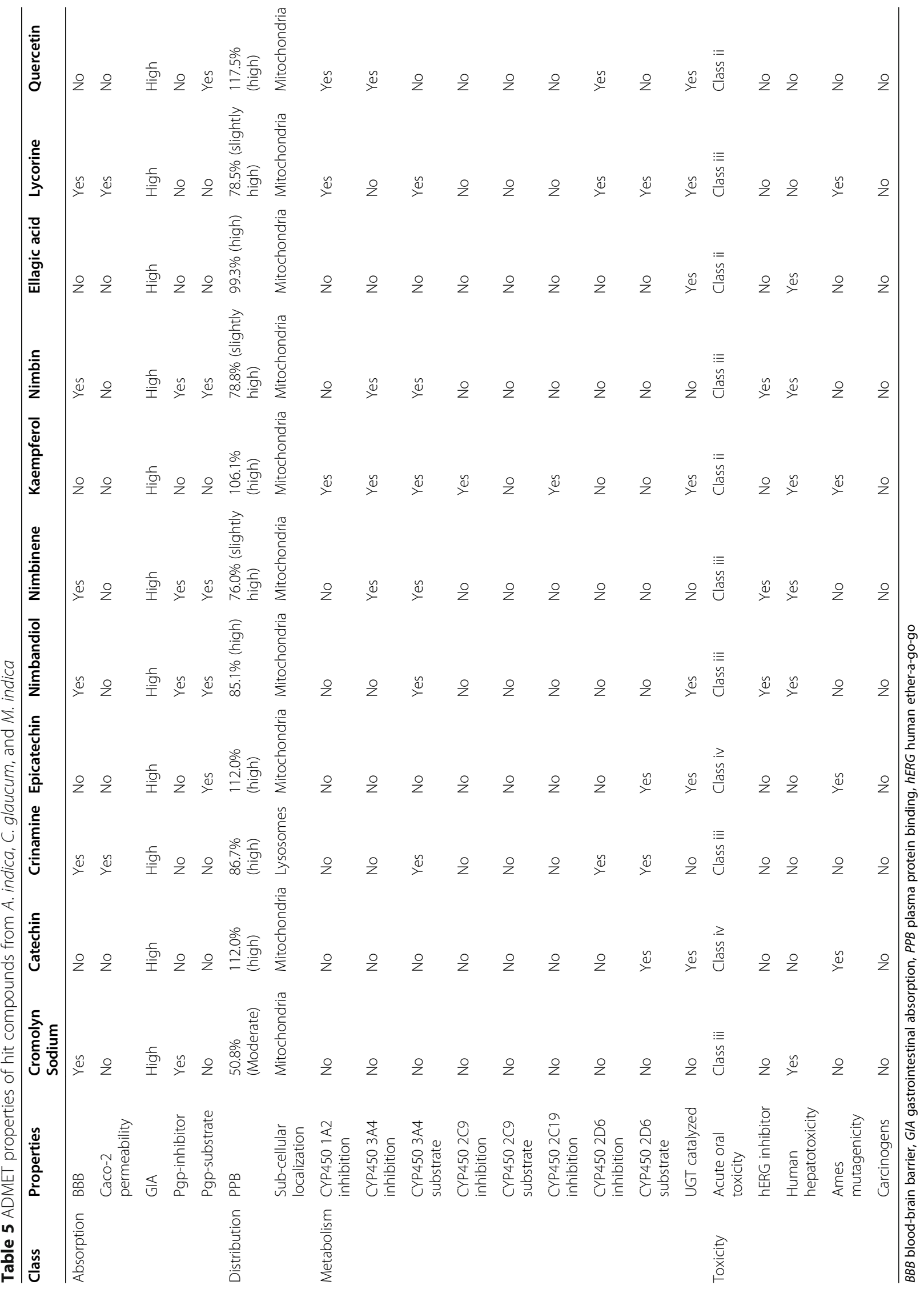


arginase because the elevated activities of either enzyme may cause deleterious consequences on airways in asthmatic patients $[4,5,9,12]$. The findings in this present in silico study indicate that all the bioactive compounds possess inhibitory potentials against NOS and arginase except for gallic acid and nimbandiol that demonstrated poor inhibitory effects against NOS and arginase, respectively. Also, this study revealed that these compounds bind to the catalytic domain in NOS enzyme. Subsequently, this inhibit the enzyme which might facilitate reduction in the production of $\mathrm{NO}$ in the asthmatic airway. The binding of these molecules were observed to lock off the entry of any incoming substrate (Figs. 3,4, 5, 6, 7, and 8). This is also confirmed by the interactions with the amino acids residues found within the catalytic domain of the enzyme which also corresponds to some of the residues that were found to interact with L-arginine (Table 3), a known substrate. The aforementioned event may prevent production of reactive nitrogen species (RNS) and consequently oxidation and nitration of proteins that can possibly ameliorate the adverse effects associated with this physiological process. Additionally, these bioactive compounds exhibit inhibitory potential against arginase enzyme as they bind to the substrate's active domain of the enzyme. Note worthily, the regulation of these two enzymes is highly germane to the sustainability of lung homeostasis which may improve bronchodilation whenever the need arises for it under varying physiological conditions.

The major bioactive components of C. glaucum which exhibits various pharmacological effects such as mast cell stabilization, anti-allergic effect, anti-spasmodic effect, and anti-anaphylactic effect are two alkaloids, Crinamine and Lycorine [26, 29]. Anti-inflammatory properties via the regulation of NF-kB, MAPKs and Nrf2 pathways had been earlier attributed to catechin while its isomer, epicatechin displayed inhibition against TNF$\alpha$, IL-6, PGE2, and nitric oxide [29, 35-37]. Kaempferol has numerous beneficial functions which include cardiovascular, antioxidant, antidiabetic, anti-inflammatory, hepatoprotective, and neuroprotective effects [29, 35-37]. Quercetin had been known for anti-inflammatory potentials, mast cell stabilizing, and gastro-intestinal cytoprotective activity. Nimbandiol, nimbinene, and nimbin are limonoids in A. indica [39] that possesses various pharmacological potentials that include as anti-inflammatory, antioxidant, antimicrobial, mast cell stabilizers, and antiviral potentials [29, 41-45]. These facts might be attributed to the performance of these bioactive compounds in our current work.

In our current in silico study; hydrogen bonds, hydrophobic interactions, and electrostatic interactions were common among the protein-ligand complexes. Interestingly, these interactions had been reported provide stability to the protein-ligand complexes, likewise influence the binding energy values of the hit compounds in complex with all the target proteins [54, 55, 57, 58]. Thus, the facts provided in this current work indicates that the active compounds of these three African plants, suggest that nimbin, nimbinene, quercetin, crinamine, lycorine, catechin, ellagic acid, epicatechin, and kaempferol may possess the most in silico inhibitory effect against NOS and Arginase through a molecular docking technique. However, these outcomes need to be validated using molecular dynamic simulation, and other wet lab studies. The studies from in silico toxicity profiling (Table 5) revealed that the hit compounds were better than the control drug, cromolyn sodium, but some will require chemosimilar or pharmacophoric modeling that will improve some key parameters relating to absorption, distribution and toxicity. These toxicological patterns might be connected to their earlier screening for druglikeness using the Lipinski's rule of five where they violated some parameters. The essence of in silico toxicity profiling cannot be over emphasized as many active compounds and therapeutics end up been rejected at clinical trial stages due to one toxicity issue to the other.

\section{Conclusion}

This study showed that the bioactive compounds from the selected medicinal plants are capable of binding to and inhibiting NOS and arginase I enzymes. The present in silico study revealed that nimbin, nimbinene, and quercetin from $A$. indica; crinamine and lycorine from C. glaucum; and catechin, ellagic acid, epicatechin, and kaempferol from $M$. indica display promising association to the binding site of both enzymes (except gallic acid and nimbandiol). From the drug-likeness screening, we found that cromolyn sodium (standard drug) is not a better drug candidate when compared to the bioactive compounds investigated in this study which also manifest in the ADMET screening. Hence, they could prove to be probable anti-asthmatic drugs. This work had been completed through molecular docking technique; there would be need for molecular dynamics simulation of at least $100 \mathrm{~ns}$ to validate the outcome of our present in silico study. However, this in silico study is just a means of predicting the activity of the bioactive compounds involved, so we strongly recommend further studies (in vitro and in vivo) to validate the efficacy of these bioactive compounds.

\section{Abbreviations}

eNOS: Endothelial NOS; NOS: Nitric oxide synthase; NO: Nitric oxide; RNS: Reactive nitrogen species; ROS: Reactive oxygen species; PDB: Protein Data Bank; MMFF94: Merck molecular force field 94; GIA: Gastrointestinal absorption; BBB: Blood-brain barrier; CYP: Cytochrome P450; herG: Human either-a-go-go 


\section{Acknowledgements}

Not applicable.

\section{Authors' contributions}

HIU: conceptualization, methodology, investigation, writing of original draft; TPS: methodology, investigation, writing of original draft; AA: methodology, investigation, writing of original draft; SSJ: investigation, writing, reviewing and editing; JBD: methodology, writing, reviewing and editing of the manuscript. All authors have read and approved the manuscript for publication.

\section{Funding}

Not applicable.

Availability of data and materials

We declare that all the data generated are included in this study.

\section{Declarations}

\section{Ethics approval and consent to participate}

Not applicable.

\section{Consent for publication}

Not applicable.

\section{Competing interests}

The authors declare that they have no competing interests.

\section{Author details}

'Department of Biochemistry, Federal University of Technology, P. M. B. 704, Akure, Ondo State, Nigeria. ${ }^{2}$ Computer-Aided Therapeutic Discovery and Design Group, FUTA, Akure, Nigeria. ${ }^{3}$ Department of Biochemistry and Molecular Biology, Federal University, Birnin Kebbi, Kebbi State, Nigeria.

\section{Received: 23 March 2021 Accepted: 11 May 2021}

Published online: 23 June 2021

\section{References}

1. Xu G, Chen Y, Shen K, Wang X, Li F, He Y (2014) The discovery of potentially selective human neuronal nitric oxide synthase (nNOS) inhibitors: a combination of pharmacophore modeling, CoMFA, virtual screening and molecular docking studies. Int J Mol Sci 15(5):8553-8569. https://doi.org/1 0.3390/ijms 15058553

2. Gabriela M, Subhash CA, Jailall R, Shawn PM, Suman R, John SA et al (2012) First-in-class, dual-action, 3,5-disubstituted indole derivatives having human nitric oxide synthase (nNOS) and norepinephrine reuptake inhibitory (NERI) activity for the treatment of neuropathic pain. J Med Chem 55:3488-3501

3. Dothi S, Ganugapati J, Valluri V, Macha R, Sivasai KS (2018) Molecular docking studies of ephedrine, eugenol, and their derivatives as arginase inhibitors: implications in asthma. Int J. Pharma Investig 8(3):130-137. https://doi.org/10.4103/jphi.JPH_25_18

4. Caldwell RB, Toque HA, Narayanan SP, Caldwell RW (2015) Arginase: an old enzyme with new tricks. Trends Pharmacol Sci 36:395-405 [CrossRef] [PubMed]

5. Pham T, Bordage S, Pudlo M, Demougeot C, Thai K, Girard-Thernier C (2016) Cinnamide derivatives as mammalian arginase inhibitors: synthesis, biological evaluation and molecular docking. Int J Mol Sci 17(10):1656. https://doi.org/10.3390/ijms17101656

6. Munzel T, Feil R, Mulsch A, Lohmann SM, Hofmann F, Walter U (2003) Physiology and pathophysiology of vascular signaling controlled by guanosine 3', 5'-cyclic monophosphate-dependent protein kinase. Circulation 108(18):2172-2183. [PubMed: 14597579]. https://doi.org/10.1161/ 01.CIR.0000094403.78467.C3

7. Papapetropoulous A, Simoes DC, Xanthou G, Roussos C, Gratziou C (2006) Soluble guanylyl cyclase expression is reduced in allergic asthma. Amer $J$ Physio 290:L179-L184 [PubMed: 16143586]

8. Ricciardolo FL, Geppetti P, Mistretta A, Nadel JA, Sapienza MA, Bellofiore S, Di Maria GU (1996) Randomized double-blind placebo-controlled study of the effect of inhibition of nitric oxide synthesis in bradykinin-induced asthma. Lancet 348(9024):374-377. [PubMed: 8709736]. https://doi.org/10.1 016/S0140-6736(96)04450-9
9. Ghosh S, Erzurum SC (2011) Nitric oxide metabolism in asthma pathophysiology. Biochim Biophys Acta 1810(11):1008-1016. https://doi. org/10.1016/j.bbagen.2011.06.009

10. Frieri M (2005) Asthma concepts in the new millennium: update in asthma pathophysiology. Allergy Asthma Proc 26(2):83-88. [PubMed: 15971464]

11. lijima H, Duguet A, Eum SY, Hamid Q, Eidelman DH (2001) Nitric oxide and protein nitration are eosinophil dependent in allergen-challenged mice. Am J Resp Crit Care Med 163(5):1233-1240. [PubMed: 11316664]. https://doi. org/10.1164/ajrccm.163.5.2003145

12. North LM (2011) L-arginine metabolism in the lungs: reciprocal regulation of the NOS and arginase pathways. Open Nitric Oxide J 3(1):48-54. https:// doi.org/10.2174/1875042701103010048

13. Taur DJ, Patil RY (2011) Some medicinal plants with antiasthmatic potential: a current status. A Pac J Trop Biomed 1(5):413-418. https://doi.org/10.1016/ S2221-1691(11)60091-9

14. Slader CA, Reddel HK, Jenkins CR, Armour CL, Bosnic Anticevich SZ (2006) Complementary and alternative medicine use in asthma: who is using what? Respirol 11(4):373-387. https://doi.org/10.1111/j.1440-1843.2006. 00861.x

15. Ernst M, Grace OM, Saslis-Lagoudakis CH, Nilsson N, Simonsen HT, Ronsted N (2015) Global medicinal uses of Euphorbia L. (Euphorbiaceae). J Ethnopharmacol 176:90-101 [CrossRef] [PubMed]

16. Gozubuyuk GS, Aktas E, Yigit N (2014) An ancient plant Lawsonia inermis (henna): determination of in vitro antifungal activity against dermatophytes species. J Mycol Med 24:313-318 [CrossRef] [PubMed]

17. Hotwani K, Baliga S, Sharma K (2014) Phytodentistry: use of medicinal plants. J Complement Integr Med 11:233-251 [CrossRef] [PubMed]

18. Liu Q, Lawrence AJ, Liang JH (2011) Traditional Chinese medicine for treatment of alcoholism: from ancient to modern. Am J Chin Med 39:1-13 [CrossRef] [PubMed]

19. Mannangatti $P$, Naidu KN (2016) Indian herbs for the treatment of neurodegenerative disease. Adv Neurobiol 12:323-336. [PubMed]. https:// doi.org/10.1007/978-3-319-28383-8_17

20. McGovern PE, Mirzoian A, Hall GR (2009) Ancient Egyptian herbal wines. Proc Natl Acad Sci U S A 106:7361-7366 [CrossRef] [PubMed]

21. Thomford NE, Senthebane DA, Rowe A, Munro D, Seele P, Maroyi A, Dzobo $K$ (2018) Natural products for drug discovery in the $21^{\text {st }}$ century: innovations for novel drug discovery. Int J Mol Sci 19(6):1578. https://doi.org/10.3390/ ijms19061578

22. Friedewald VE Jr, Friedewald VE (2008) Asthma Microsoft student 2008. DVD. Microsoft Corporation, Redmond

23. Ladejobi TA (2001) Studies on the medicinal species of Sennaa in Nigeria. A B. Tech research project report, Department of Pure and Applied Biology, Ladoke Akintola University of Technology, Ogbomoso, Nigeria.

24. Ogunkunle ATJ, Olopade OR (2011) Studies on the asthma coughs plant Crinum jagus L. (Amaryllidaceae) in Nigeria. Afr J Plant Sci 5(2):108-114

25. Greenberger PA (2003) Therapy in management of rhinitis-asthma complex. Allergy Asthma Proc 24(6):403-407

26. Okpo SO, Adeyemi OO (2002) The anti-allergic effects of Crinum glaucum aqueous extract. Phytomedicine 9(5):438-441. https://doi.org/10.1078/0944 7110260571698

27. Gbile ZO (1984) Vernacular names of Nigerian plants, vol 39. Forestry research institute of Nigeria, Ibadan

28. Ishola IO, Olayemi SO, Idowu AR (2013) Anticonvulsant, anxiolytic and hypnotic effects of aqueous bulb extract of Crinum glaucum A. Chev (Amaryllidaceae): Role of GABAergic and nitrergic systems. Pak J Biol Sci 16(15):701-710. https://doi.org/10.3923/pjbs.2013.701.710

29. Mali RG, Dhake AS (2011) A review on herbal anti-asthmatics. Orient Pharm Exp Med 11(2):77-90. https://doi.org/10.1007/s13596-011-0019-1

30. Hirano R, Oo TH, Watanabe KN (2010) Myanmar mango land races reveal genetic uniqueness over common cultivars from Florida, India, and Southeast Asia. Genome 53(4):321-330. https://doi.org/10.1139/G10-005

31. Saúco VG (2004) Mango production and world market: current situation and future prospects. Acta Horticult 645:107-116

32. Ediriweera MK, Tennekoon KH, Samarakoon SR (2017) A review on ethnopharmacological applications, pharmacological activities and bioactive compounds of Mangifera indica (Mango). Evid Based Complement Alternat Med 2017:1-24. https://doi.org/10.1155/2017/6949835

33. Barreto JC, Trevisan MTS, Hull WE, Erben G, de Brito ES, Pfundstein B, Würtele G, Spiegelhalder B, Owen RW (2008) Characterization and quantitation of polyphenolic compounds in bark, kernel, leaves, and peel of 
mango (Mangifera indica L.). J Agric Food Chem 56(14):5599-5610. https:// doi.org/10.1021/jf800738r

34. Nayan V, Onteru SK, Singh D (2017) Mangifera indica flower extract mediated biogenic green gold nanoparticles: efficient nanocatalyst for reduction of 4-nitrophenol, environmental progress \& sustainable energy

35. Garrido-Garrido G, Martínez-Sánchez G, Pardo-Andreu G, García-Rivera D, Hernández-Casaña P, Rodeiro-Guerra I et al (2007) Recent advances in the research \& development of an aqueous stem bark extract obtained from Mangifera indica L. In: Capasso A (ed) Recent developments in medicinal plant research, vol 9, pp 169-192

36. Rivera DG, Balmaseda IH, León AA, Hernández BC, Montiel LM, Garrido GG, Cuzzocrea S, Hernández RD (2006) Anti-allergic properties of Mangifera indica L. extract (VIMANG) and contribution of its glucosylxanthonemangiferin. J Pharm Pharmacol 58(3):385-392. https://doi. org/10.1211/jpp.58.3.0014

37. Alvarez A, Sanchez C, García D, Rodríguez J, Lemus Y, Jane A et al (2009) Treatment of bronchial asthma with an aqueous extract of Mangifera indica L. (VIMANG $\left.{ }^{\circledR}\right)$ two cases report. Bol Latinoam Caribe Plant Med Aromat 8(2): 63-66

38. Lee J, Ryu HW, Park S, Park HA, Kwon O, Yuk HJ, Ahn K (2017) Protective effects of neem (Azadirachta indica A. Juss.) leaf extract against cigarette smoke- and lipopolysaccharide-induced pulmonary inflammation. Int J Mol Med 40:1932-1940. https://doi.org/10.3892/ijmm.2017.3178

39. Okpanyi SN, Ezeukwu GC (2017) Anti-inflammatory and anti-pyretic activities of Azadirachta indica. Planta Med 41:34-39 1981. View Article : Google Scholar : PubMed/NCBI

40. Rao AD, Devi KN, Thyagaraju K (1998) Isolation of antioxidant principle from Azadirachta seed kernels: determination of its role on plant lipoxygenases. J Enzyme Inhib 14:85-96 View Article : Google Scholar

41. Yanpallewar SU, Sen S, Tapas S, Kumar M, Raju SS, Acharya SB (2003) Effect of Azadirachta indica on paracetamol-induced hepatic damage in albino rats. Phytomedicine 10:391-396 View Article: Google Scholar : PubMed/NCBI

42. Almas K (1999) The antimicrobial effects of extracts of Azadirachta indica (Neem) and Salvadora persica (Arak) chewing sticks. Indian J Dent Res 10(1):23-26

43. Badam L, Joshi SP, Beldekas SS (1999) In vitro antiviral activity of neem (Azadirachta indica. A Juss) leaf extract against group B coxsackieviruses. J Commun Dis 31(2):79-90

44. Pingale SS (2010) Hepatoprotection study of leaves powder of Azadirachta indica A. Juss. Int J Pharmaceut Sci Rev Res 3(2):37-42

45. Kumawat KR, Kumar R (2018) Pharmacological and therapeutical overview of neem (Azadirachta indica): A nature's drug store. Int J Chem Sci 2(2):23-27

46. Sekar V, Chakraborty S, Mani S, Sali VK, Vasanthi HR (2019) Mangiferin from Mangifera indica fruits reduces post-prandial glucose level by inhibiting aglucosidase and a-amylase activity. S Afr J of Bot 120:129-134. https://doi. org/10.1016/j.sajb.2018.02.001

47. Lipinski CA (2008) Drug-like properties and the causes of poor solubility and poor permeability. J Pharmacol Toxicol Methods 44:235-249

48. Lipinski CA, Lombardo F, Dominy BW, Feeney PJ (2001) Experimental and computational approaches to estimate solubility and permeability in drug discovery and development settings. Adv. Drug Delivery Rev 46(1-3):3-26. https://doi.org/10.1016/S0169-409X(00)00129-0

49. Trott O, Olson AJ (2010) AutoDock Vina: improving the speed and accuracy of docking with a new scoring function, efficient optimization, and multithreading. J Comput Chem 31:455-461

50. Warshaneyan SS, Srivastava P (2019) Analysis and subsequent molecular docking of selected phytochemicals with SLC6A3 and SLC6A4 as potential therapeutic agents for Obsessive-Compulsive Disorder (OCD). Bio Rxiv:129-134

51. Salentin S, Schreiber S, Haupt VJ, Adasme MF, Schroeder M (2015) PLIP: fully automated protein-ligand interaction profiler. Nucleic Acids Res 43(W1): W443-W447. https://doi.org/10.1093/nar/gkv315

52. Li H, Jamal J, Plaza C, Pineda SH, Chreifi G, Jing Q, Cinelli MA, Silverman RB, Poulos TL (2014) Structures of human constitutive nitric oxide synthases. Acta Crystallogr D70(10):2667-2674. https://doi.org/1 $0.1107 / S 1399004714017064$

53. Fischmann TO, Hruza A, Da Niu X, Fossetta JD, Lunn CA, Dolphin E et al (1999) Structural characterization of nitric oxide synthase isoforms reveals striking active-site conservation. Nat Struct Biol 6(3):233-242 http://structbio. nature.com. https://doi.org/10.1038/6675

54. Hari S (2019) In silico molecular docking and ADME/T analysis of plant compounds against IL17A and IL18 targets in gouty arthritis. J Appl Pharmaceutical Sci 9(07):018-026. https://doi.org/10.7324/JAPS.2019.90703

55. Usha T, Tripathi P, Pande V, Middha SK (2013) Molecular docking and quantum mechanical studies on pelargonidin-3-glucoside as renoprotective ACE Inhibitor". Int Sch Res Notices 2013(Article ID 428378):4. https://doi. org/10.1155/2013/428378.

56. Brooks BR, Brooks CL, Mackerell AD, Nilsson L, Petrella RJ, Roux B et al (2009) CHARMM: the Bio-molecular simulation Program. Comput Chem 30(10): 1545-1615. https://doi.org/10.1002/jcc.21287

57. Usha T, Middha SK, Goyal AK, Karthik M, Manoj DA, Faizan S et al (2014) Molecular docking studies of anti-cancerous candidates in Hippophae rhamnoides and Hippophae salicifolia. J Biomed Res 28(5):406-415. https:// doi.org/10.7555/JBR.28.20130110

58. Singh SP, Konwar BK (2012) Molecular docking studies of quercetin and its analogues against human inducible nitric oxide synthase. SpringerPlus 1(1): 69. https://doi.org/10.1186/2193-1801-1-69

\section{Publisher's Note}

Springer Nature remains neutral with regard to jurisdictional claims in published maps and institutional affiliations.

\section{Submit your manuscript to a SpringerOpen ${ }^{\circ}$ journal and benefit from:}

- Convenient online submission

- Rigorous peer review

- Open access: articles freely available online

- High visibility within the field

- Retaining the copyright to your article

Submit your next manuscript at $\boldsymbol{\nabla}$ springeropen.com 